\title{
Erratum: Doing theology with children in a South African context: Children as collaborators in intergenerational ministry
}

\begin{tabular}{|c|c|}
\hline \multicolumn{2}{|c|}{$\begin{array}{l}\text { Authors: } \\
\text { Shantelle Weber } \\
\text { Stephan de Beer }{ }^{2,3}\end{array}$} \\
\hline \multicolumn{2}{|c|}{$\begin{array}{l}\text { Affiliations: } \\
{ }^{1} \text { Department of Practical } \\
\text { Theology and Missiology, } \\
\text { University of Stellenbosch, } \\
\text { South Africa }\end{array}$} \\
\hline \multicolumn{2}{|c|}{$\begin{array}{l}{ }^{2} \text { Centre for Contextual } \\
\text { Ministry, Faculty of Theology, } \\
\text { University of Pretoria, } \\
\text { South Africa }\end{array}$} \\
\hline \multicolumn{2}{|c|}{$\begin{array}{l}{ }^{3} \text { Department of Practical } \\
\text { Theology, Faculty of } \\
\text { Theology, University of } \\
\text { Pretoria, South Africa }\end{array}$} \\
\hline \multicolumn{2}{|c|}{$\begin{array}{l}\text { Project leader: S.F. de Beer } \\
\text { Project number: } 86233689\end{array}$} \\
\hline \multicolumn{2}{|c|}{$\begin{array}{l}\text { Description: } \\
\text { This research is part of the } \\
\text { research project, 'Social } \\
\text { Justice and Reconciliation', } \\
\text { which is directed by } \\
\text { Dr Stephan de Beer, } \\
\text { Director of the Centre for } \\
\text { Contextual Ministry and } \\
\text { member of the Department } \\
\text { of Practical Theology, } \\
\text { Faculty of Theology, } \\
\text { University of Pretoria. }\end{array}$} \\
\hline \multicolumn{2}{|c|}{$\begin{array}{l}\text { Corresponding author: } \\
\text { Stephan de Beer, } \\
\text { stephan.debeer@up.ac.za }\end{array}$} \\
\hline \multicolumn{2}{|c|}{$\begin{array}{l}\text { Dates: } \\
\text { Published: } 27 \text { Jan. } 2017\end{array}$} \\
\hline \multicolumn{2}{|l|}{ Read online: } \\
\hline 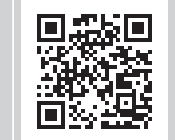 & $\begin{array}{l}\text { Scan this QR } \\
\text { code with your } \\
\text { smart phone or } \\
\text { mobile device } \\
\text { to read online. }\end{array}$ \\
\hline
\end{tabular}

The Publisher regrets that the affiliation of Shantelle Weber and Stephan de Beer were incorrectly recorded during the final editing process of the article.

The correct affiliation of Shantelle Weber is:

Department of Practical Theology and Missiology, University of Stellenbosch, South Africa.

The correct affiliations for Stephan de Beer are:

Centre for Contextual Ministry, Faculty of Theology, University of Pretoria, South Africa and Department of Practical Theology, Faculty of Theology, University of Pretoria, South Africa.

The Publisher apologises.
How to cite this article: Weber, S. \& De Beer, S., 2017, 'Erratum: Doing theology with children in a South African context: Children as collaborators in intergenerational ministry', HTS Teologiese Studies/Theological Studies 72(1), a3572. https://doi.org/10.4102/hts. v72i1.3572-01

Copyright: (C) 2017. The Authors. Licensee: AOSIS. This work is licensed under the Creative Commons Attribution License. Note: Doi of original article: http://dx.doi.org/10.4102/hts.v72i1.3572 